\title{
Szép új digitális világ? - A pénzügyi technológia és az információ hatalma*
}

\author{
Kerényi Ádám - Müller János
}

A tanulmány, középpontjában a FinTech fejlödésével, azt járja körül, hogy a jelenség hogyan értékelhető és kezelhető az egyes kiválasztott régiókban, az Európai Unióban, Kínában és Magyarországon. Az alapvető kérdések: Hogyan tudnak a szabályozók lépést tartani a gyors fejlödéssel? A szabályozás támaszkodhat-e egy pontos FinTech-definícióra, és biztosithatók-e az egyenlö versenyfeltételek a bankok és a FinTech startupok számára? Milyen kockázatokkal kell számolni, és hogyan kezelheti ezeket a felügyelet és a szabályozás? Megállapitható, hogy a FinTech egy "forradalmi" folyamat első lépése, és a jelenség meghatározása igen tág és folyamatosan változik. A szabályozóknak és felügyeleti hatóságoknak úgy kell alakítaniuk a feltételeket, hogy a hagyományos bankokra és a FinTech vállalatokra egyenlö versenyfeltételek érvényesüljenek, és azonos legyen a kockázatkezelésük. Minden szereplőnek megvan a maga felelössége, beleértve a központi bankokat, a szabályozó- és a felügyeleti hatóságokat, a hagyományos bankokat, a fogyasztókat és a FinTech vállalatokat. Az információ hatalom, és számos közgazdász azt állítja, hogy a digitális az új normalitás. Tanulmányunkban részben igazoljuk a megállapitás első felét, és kérdőjelet teszünk a második fele után.

Journal of Economic Literature (JEL) kódok: D74, G21, O33, N74

Kulcsszavak: forradalmak, pénzügyi intézmények és szolgáltatások, technológia, diffúziós folyamatok

\footnotetext{
* A jelen kiadványban megjelenő írások a szerzők nézeteit tartalmazzák, ami nem feltétlenül egyezik a Magyar Nemzeti Bank hivatalos álláspontjával.

Kerényi Ádám a Magyar Tudományos Akadémia Világgazdasági Intézetének kutatója.

E-mail: kerenyi.adam@krtk.mta.hu

Müller János közgazdász, a Magyar Bankszövetség vezető tanácsadója és a Bank of China Hungary Ltd. igazgatóságának tagja.

E-mail: mullerj1@t-online.hu

Kerényi Ádám köszönettel tartozik a Nemzeti Kutatási, Fejlesztési és Innovációs Hivatal által nyújtott támogatásért. A K 128682 számú projekt a Nemzeti Kutatási Fejlesztési és Innovációs Alapból biztosított támogatással, a K_18 pályázati program finanszírozásában valósult meg.

Az angol nyelvű kézirat első változata 2018. június 25-én érkezett szerkesztőségünkbe.
} 


\section{Hamarosan kezdetét veszi a technológiai és digitális forradalom újabb fejezete}

A világ jelenkori fejlődésének egyik legizgalmasabb jelensége a digitalizáció. Üteme, térhódítása és társadalmi hatása oly gyors és mélyreható, hogy sokan a negyedik ipari forradalom részének tekintik. Ennek a folyamatnak egy kisebb, de szerepe szempontjából fontosabb része a pénzügyi, banki területen való megjelenése, amire röviden FinTech-mániaként hivatkoznak.

Az események pontosabb megértése érdekében röviden áttekintjük a második és harmadik ipari forradalom következményeit, és három régióra - az Európai Unióra, Kínára és Magyarországra - koncentrálva vizsgáljuk a FinTech-mánia jelenlegi helyzetét és megközelítését. Azért választottuk ezt a kutatási témát, mert az Európai Unió nem csupán a FinTech fejlődésében tölt be kulcsfontosságú szerepet, hanem definiálásában, szabályozásában, illetve felügyeleti kérdéseiben is. A kínai megközelítés szintén figyelemre méltó, hiszen a tapasztalatok szerint Kína hasonló felügyeleti és szabályozói kihívásokkal szembesül, és ott is erősen támogatják a FinTech fejlődését. Ezért mutatjuk be az alábbiakban a FinTech-befektetések közelmúltbeli adatait. Az ábrák és az adatok két fő következtetést támasztanak alá: a FinTech-befektetések Ázsiában és Európában egyaránt növekednek, és egyre magasabb szintet érnek el (lásd 1. és 2. ábra). Az is látható, hogy Európa egyelőre magasabb szintre jutott, mint Ázsia. Mindazonáltal egy ilyen összehasonlítás esetén óvatosnak kell lennünk, ugyanis az ábra Ázsiát jelölő vonala az egész ázsiai térséget magában foglalja, és nem áll rendelkezésre a megfelelő kínai adat a kínai és az európai fejlettség összehasonlításához.

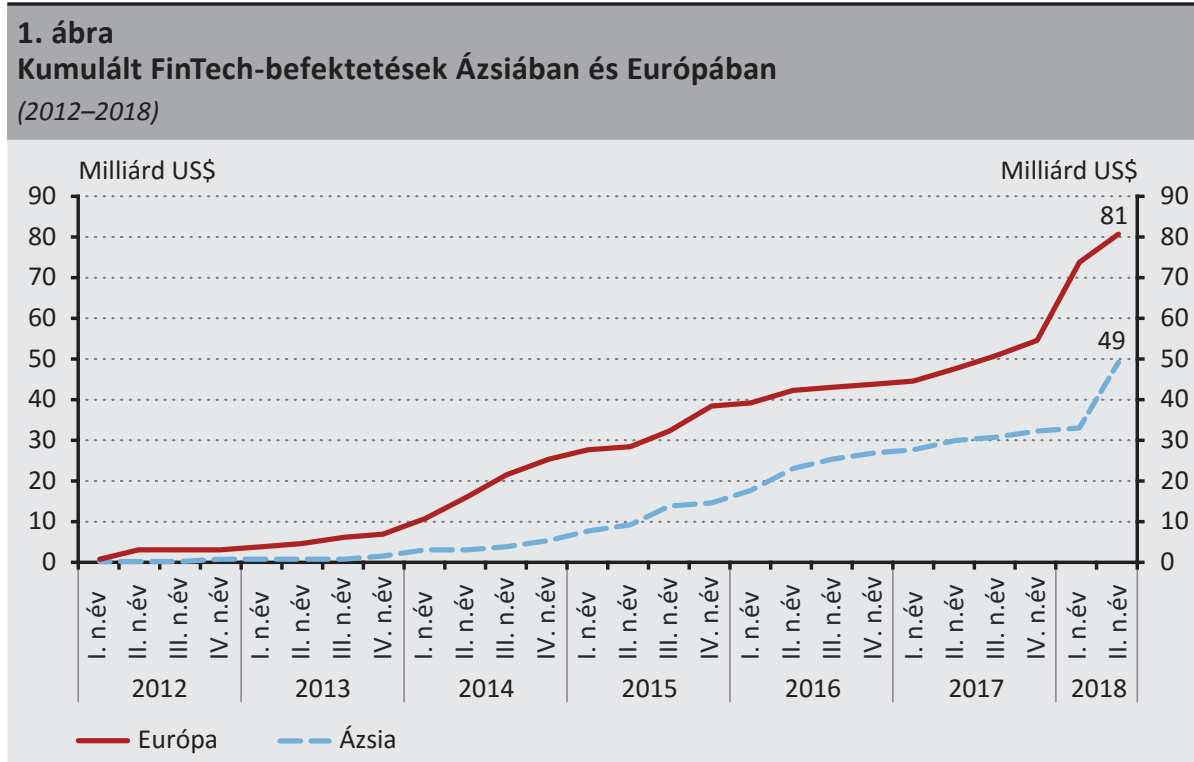

Forrás: KPMG $(2018,34$. és 47. o.) 


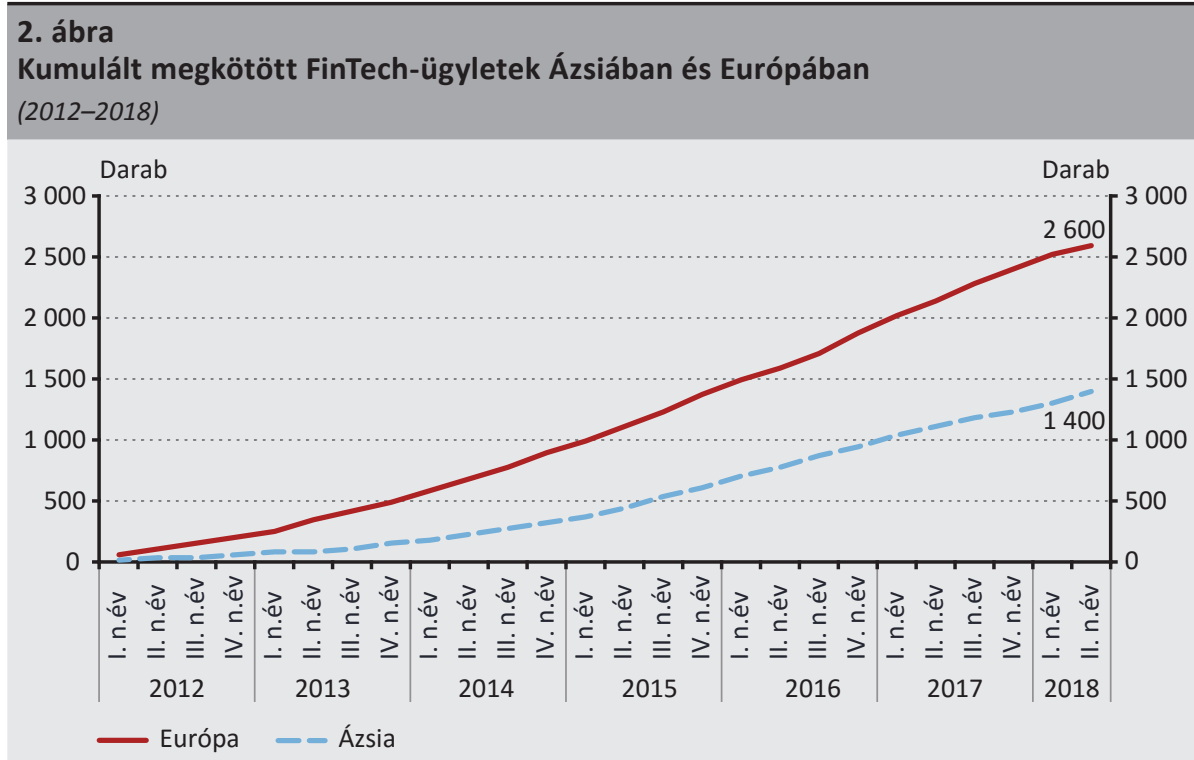

Forrás: KPMG $(2018,34$. és 47. o.)

Később bemutatjuk a magyar helyzetet is, ahol a FinTech-fejlesztések több okból csak némi késéssel indultak el, ám az utóbbi években nagy lépéseket tettünk a nemzetközi szinthez való felzárkózás irányába.

A 21. század kezdete óta a digitális átalakulás részesei vagyunk, vagyis a digitális technológiákhoz kapcsolódó innovációk a társadalom és a gazdaság valamennyi szegmensét érintik. A negyedik ipari forradalom megkezdődött és jelenleg is zajlik. Az Ipar 4.0 válaszokat ad az előttünk álló kihívásokra. Számos közgazdász úgy véli, hogy a digitális az új normalitás. Meglátásunk szerint érdemes a kijelentés végére kérdőjelet tenni. A jelenlegi gyors változások időszakában nem tudjuk, hogyan fest majd végül az „új világ”. „A hírekben a pénzügyi technológiákat »felforgatóként «, »forradalmiként« jellemzik, amelyek »digitális fegyverekkel« »lebontják« a korlátokat és a hagyományos pénzügyi intézményeket" (WEF 2017). Ez a feltartóztathatatlan, forradalmi jelenség egyre több helyet követel magának mindennapi életünkben. Természetesen ezek a változások - legyenek akár forradalmiak, akár csak úgy érzékeltek - a pénzügyi- és bankszektort is elérték. A pénzügyi technológia („FinTech”) tág fogalom. Melyek az európai jogalkotók és felügyeleti hatóságok főbb aggályai? Először is a digitális pénzügyi technológiák rendkívül gyorsan fejlődnek, olyannyira, hogy már a FinTech-jelenség pontos meghatározása is nehézségekbe ütközik. Amennyiben a definíció tág, leginkább gyújtőfogalmat takar, a jogi keretek és a megfelelő felügyelet részletezése szintén körülményes, és nem lehet kielégítő. A felügyeleti hatóságok nem járnak a fejlemények előtt, inkább csak igyekeznek utolérni őket. Az „azonos kockázat, azonos szabályozás” elvét egyelőre nem lehet érvényesíteni. 
A definíció problémájánál maradva a FinTech fogalma magában foglalja a digitális főkönyvi technológiát, a robottanácsadókat, a RegTech-megoldásokat (a megfelelőségi és adatszolgáltatási kötelezettségek teljesítésére használható technológiákat), valamint a virtuális pénzeket. Ebben a tanulmányban a FinTech-jelenség pontosabb megértésére, valamint a hagyományos bankok és a FinTech startupok közötti lehetséges kapcsolatokra koncentrálunk.

A pénzügyi technológia ${ }^{1}$ a pénzügyi szolgáltatások egyik leginnovatívabb, egyre fontosabb és potenciálisan leggyorsabban változó területe, amely forradalmasítja a pénzügyi szolgáltatók múködését. Átalakítja a hitel- és részvénypiacokat, a pénzforgalmat, a hitelbírálatokat, a szabályozói megfelelést, a személyi pénzügyeket és a pénzügyi szolgáltatások számos egyéb szegmensét. Noha azt hihetnénk, hogy a FinTech pusztán egy újabb divatszó, meggyőződésünk, hogy a technológia lehetőséget teremt arra, hogy drámaian átalakítsa a pénzügyek ma ismert arculatát. A digitalizáció már az üzleti élet és mindennapjaink valamennyi területén megfigyelhető, átalakítja a szolgáltatásokat, és újakat hoz létre, amelyeket a FinTech-vállalatok felgyorsítanak (Deloitte 2016). A FinTech hívei szerint eljött a FinTech aranykora, ugyanakkor a FinTech-et övező jelenlegi mánia nem a technológiák állítólagos forradalmi természetéből, hanem jobb láthatóságukból fakad. Anélkül, hogy megkérdőjeleznénk a kézzelfogható kedvező hatásokat, a FinTech-jelenség jelenlegi helyzetére és annak nemzetközi megítélésére, a jövőbeli kilátások előrejelzésének nehézségeire, valamint a hagyományos bankrendszerbeli paradigmaváltás szükségességére szeretnénk koncentrálni. Utóbbival szoros összefüggésben áttekintjük a bankok és FinTech-vállalatok kapcsolatának várható fejlődését, és - végül, de nem utolsó sorban - jelenlegi és jövőbeli ügyfeleiket. Végezetül fontos kérdés, hogy vannak-e a FinTech-szolgáltatások használatának kockázatai. Amennyiben igen, hogyan lehet ezeket csökkenteni vagy orvosolni új szabályozói vagy felügyeleti intézkedésekkel? Az egyik első kérdés, amelyet tisztázni kell az, hogy hol állunk most a digitális technológiák fejlődésében. Még csak a folyamat kezdetén járunk, vagy már a folyamatos fejlődés kiegyensúlyozott, nyugodt fázisában élünk? Hol helyezkednek el a hagyományos bankok ebben a folyamatban? Véleményünk szerint a rövid és helyes válasz az, hogy pontosan nem tudjuk. A kérdés megválaszolásában sokat segíthet a múlt tapasztalatainak áttekintése.

Amikor a digitalizáció, a mesterséges intelligencia és a FinTech-fejlesztések eredményeit, és az emberi és társadalmi kapcsolatokra kifejtett hatásukat vizsgáljuk, szinte

\footnotetext{
${ }^{1}$ Egyes kutatók a FinTech-jelenséget technológia-vezérelt pénzügyi megoldásokként definiálják (Arner et al. 2015). Értelmezésükben a fogalom nem korlátozódik bizonyos banki tevékenységekre (pl. finanszírozás) vagy üzleti modellekre (pl. személyközi hitelezés, alkalmazások), hanem magában foglalja azokat a termékeket és szolgáltatásokat is, amelyeket hagyományosan a bankok biztosítottak az ügyfeleiknek. Mások (Kerényi - Molnár 2017; Kerényi et al. 2018; McAuley 2015; Kim et al. 2016) tágabban értelmezik a jelenséget, és a pénzügyi rendszerek hatékonyságát növelő technológiákat használó vállalatokból álló gazdasági ágazatként határozzák meg. Az EKB álláspontja szerint a FinTech gyűjtőfogalom, amely az üzleti modellek széles körét foglalja magában. Az EKB feladatának megfelelően útmutatót tett közzé a technológiák által támogatott banki termékekről és szolgáltatásokról (EKB 2017).
} 
kézenfekvő összehasonlítani a harmadik ipari forradalom következményeit a negyedikével, mivel az utóbbi része a digitális kor is. A nyugati civilizáció már három ipari forradalomnak is tanúja volt, amelyeket úgy is lehet jellemezni, hogy bár felforgató, de nagy lépéseket eredményeztek az ipari folyamatokban, jelentősen megnövelve a termelékenységet. Az első a vízenergia használata, a gőzenergia egyre elterjedtebb alkalmazása és a gépesített szerszámok révén növelte a hatékonyságot. A második elhozta az elektromos áramot és a tömegtermelést (futószalag), a harmadik, azaz a legutóbbi pedig az elektronika és az informatika révén tovább fokozta az automatizációt. A negyedik ipari forradalom pedig folyamatban van.

Az első három forradalom következményeit már ismerjük, a negyedik lehetséges hatásait azonban még nem (Li 2017).

Míg egyes területeken gyors és robbanásszerü változások mennek végbe, mások lassan, fokozatosan alakulnak át, sokkal kisebb lépésekben. Akárhogy is, nincs visszaút. Ebben a forradalomban a fizikai tárgyak az információs hálózat szerves részévé válnak. Az internet intelligens gépekkel, termelési rendszerekkel és folyamatokkal egyesülve bonyolult hálózatot alkot. A való világ hatalmas informatikai rendszerré alakul át. Ezért koncentrálunk a pénzügyi szektornak ebben az új, forradalmi szakaszban betöltött szerepére.

A filozófusok még több évtizeddel a harmadik ipari forradalom kezdete után is hiába próbálták meg összefoglalni a gépek és az emberek közötti kapcsolat természetét és leírni nézeteiket a gépkorszaknak az emberi gondolkodásra és viselkedésre kifejtett hatásáról. Megítélésünk szerint ezek a kérdések a digitális átmenet korában jogosak vagy legalábbis azok lehetnek, és a hagyományos bankok és ügyfeleik kapcsolatának átalakulásának vizsgálatakor is jó okkal merülnek fel.

A technológiai fejlődés egyre gyorsul. A Moore-törvényként ismert empirikus megfigyelés szerint a technikai fejlesztések, illetve bizonyos részfolyamataik exponenciális növekedési pályát írnak le (Brock 2006; Kurzweil 2006). A pénzügyi szolgáltatások digitális átalakulásának kérdése manapság gyakori téma a pénzügyi rendszer és a bankszektor vizsgálatakor és elemzésekor. Napjainkban egy pénzügyi konferencia nem felelne meg a főáramú elvárásoknak, ha nem szerepelne legalább egyszer a „FinTech” szó a programjában. A vélemények és megállapítások sok tekintetben egyeznek: üdvözölni kell az új jelenségeket, a növekvő hatékonyságot, az ügyfélszolgáltatások javuló minőségét, valamint a verseny gyorsulását és erősödését. Ezek a vitathatatlan változások kétségkívül mind előremutatók. Van azonban a már folyamatban lévő fejlődésnek és trendeknek sok olyan szempontja, amelyekben nem annyira nagy az egyetértés és az összhang, és ezeken a területeken nem fogalmazódnak meg fontos, FinTech-kel kapcsolatos kérdések (Taylor 2017). 
A nagy múltú pénzügyi szervezetek mellett a hagyományos bankok is ki vannak téve a strukturális tehetetlenségnek, ami miatt a környezeti változásokhoz csak korlátozottan tudnak alkalmazkodni (Buenstorf 2016). A startupoknak vannak bizonyos előnyei a pénzügyi óriásokkal szemben. Az alapításukkor számított jogszabályi tőkekövetelmény, kis méretük, karcsú struktúrájuk, technológiai fejlődésük, és az, hogy a legnagyobb tehetségeket vonzzák, természetükből fakadó versenyelőnyt jelentenek számukra. Az új, kényelmesebb, ügyfélközpontú szolgáltatások átalakítják a viszonyokat. Ezért mondja egyre több szakértő, hogy a hagyományos bankoknak ideje változtatniuk a hozzáállásukon. A változás legfőbb okai a következők:

- a mobileszközök nagymértékű penetrációja,

- a digitális korban születettek (úgynevezett millenniumi generáció) növekvő száma,

- a bankokkal szembeni tartós - valós vagy vélt - bizalmatlanság,

- az ügyfelek általánosságban egyre többet várnak el,

- növekvő egyenlőtlenség - annak igénye, hogy csökkenjen a pénzügyi tudatlanság, és erősödjön a bekapcsolódás (inklúzió) a pénzügyi folyamatokba, valamint

- a FinTech hubok, laborok, akcelerátorok népszerüsége a helyi és országos politikusok és pénzügyi intézmények körében.

\section{A FinTech-fogalom meghatározásának kihívásai}

A FinTech (pénzügyi technológia) fogalmának nincs általánosan elfogadott definíciója a közgazdasági szakirodalomban. A Bázeli Bankfelügyeleti Bizottság (BCBS) a Pénzügyi Stabilitási Tanács (FSB) ideiglenes meghatározását használja a FinTech-re, amelynek értelmében jelentése „technológiavezérelt pénzügyi innováció, amely olyan új üzleti modelleket, alkalmazásokat, folyamatokat vagy termékeket eredményezhet, amelyek jelentős hatással lehetnek a pénzügyi piacokra és intézményekre, valamint a pénzügyi szolgáltatásokra". Ez a tág meghatározás a BCBS megítélése szerint pragmatikusan használható a FinTech fejlődésének jelenlegi változékonysága mellett. Ebben a helyzetben e tanulmány elemzésének és következtetéseinek középpontjában azok a hatások állnak, amelyek a FinTech révén különösen fontosak a bankok, a bankfelügyeletek és - a nap végén - az ügyfelek számára. Érdemes ugyanakkor azt is megjegyezni, hogy a FinTech fogalma a mi tanulmányunkban a hagyományos bankok és az új szereplők - akár startupok, akár nagyobb technológiai vállalatok - által létrehozott innovációk széles tárházának leírására vonatkozik.

A fentiekből is látható, hogy a központi bankok és a Bázeli Bizottság meghatározásában van egy közös vonás: a FinTech-jelenséget széleskörűen értelmezik, és úgy definiálják, hogy az lehetővé teszi a folyamatos változást és bővülést. 
A FinTech fogalma magában foglalja azokat a digitális szolgáltatásokat és technológiai fejlesztés alapú üzleti modelleket, amelyek már megjelentek a pénzügyi piacon. A FinTech-szektor térnyerése globális jelenség: az új, nem banki szereplők és startupok tömeges alapítása a fejlett piacokon (pl. Egyesült Államok, Egyesült Királyság) és a dinamikusan fejlődő piacokon (pl. India, Kína) is megfigyelhető. Sok banki területen - elsősorban a pénzforgalom, a hitelezés és a befektetési tanácsadás terén - jelentek meg FinTech-megoldásokat kínáló szolgáltatók.

A fentiekben ismertetett megengedő és tág definíció természetesen komoly következményekkel jár. Mivel a meghatározás nem azonosítja egyértelmúen a FinTech-szolgáltatások tartalmát és körét, megnehezíti a felügyeleti ellenőrzések határait kijelölő jogszabályi keretek kialakítását, valamint a hagyományos bankok és a FinTech-vállalatok közötti verseny egyenlő feltételeinek biztosítását.

A FinTech-ek befolyásolják a pénzügyi szolgáltatásokat és azok struktúráját, nyújtását és fogyasztását, de egyelőre nem sikerült domináns szerephez jutniuk.

Az innováció egyre hangsúlyosabb. Miközben a FinTech-ek a nagyobb térnyerésért harcoltak, a bankok sok esetben partneri viszonyt alakítottak ki velük, és számos együttmúködés már meg is hozta gyümölcsét. A bankok komoly összegeket áldoztak az ügyfél-elégedettség növelésére. Sok banknál olyan imponálóan jó tapasztalatokat szerezhettek az ügyfelek, mint korábban soha. Ezenkívül néhány intézmény eredményesen alakít ki új vállalati kultúrát, és fordít hátat az elmúlt évtized kiábrándító tapasztalatainak (McKinsey 2018).

Számos FinTech azzal a céllal jött létre, hogy a pénzügyi szolgáltatók új domináns szereplője legyen, de a növekedés érdekében és az ügyfelek bizalmának elnyeréséért a partnerségi kapcsolat mellett döntött. Emellett jónéhány intézmény, tanulva az elmúlt évtized kiábrándító tapasztalataiból, új vállalati kultúra kiépítésébe kezdett. Néhány pénzügyi intézmény pedig a FinTech-ek fenyegetésében lehetőséget látott (WEF 2017). Elismerve a FinTech-eknek az innovációban betöltött jelentős szerepét, kulcskérdés lesz, hogy hogyan kezelik ezt a kihívást a felügyeleti szervek és a szabályozó hatóságok.

Mint korábban említettük, a FinTech-jelenség a negyedik ipari forradalom első szakaszában jelent meg. A 2007-2008-as nemzetközi pénzügyi válság után a hagyományos bankoknak elsődleges feladatként túl kellett jutniuk a válság következményein: meg kellett tisztítaniuk a mérlegüket, megerősíteniük tőkehelyzetüket és csökkenteni kellett a nem teljesítő hitelek arányát. Alkalmazkodniuk kellett a válságból következő szigorú és bizonyos esetekben túlzó szabályozói körülményekhez, és jelentős költségcsökkentést kellett végrehajtaniuk. Emiatt a hagyományos bankok az internetes szolgáltatásokra és a digitális fejlesztésekre csak némi késéssel, az utóbbi években tudtak odafigyelni. Az elsődleges céljuk a bizalom helyreállítása és megerősítése 
volt. Ebben a helyzetben piaci rés nyílt a FinTech-vállalatok előtt, valós piaci kereslet keletkezett. A FinTech startupok alapításához kevesebb tőkére volt szükség, így gyorsan végre tudták hajtani a pénzügyi-technológiai fejlesztéseket a pénzforgalmi szolgáltatások terén. Továbbá egyes hagyományos bankok hajlandók voltak kiszervezni bizonyos pénzügyi szolgáltatásokat ${ }^{2}$ és digitális fejlesztéseket. A FinTech-szolgáltatások szabályozása és felügyelete legtöbbször csak követte a gyorsan változó eseményeket, így a harmadik fél típusú (TPP) pénzforgalmi szolgálatásokat kevésbé szigorúan szabályozták, mint a hagyományos bankokat.

Az elkövetkező tíz évben a bankolás talán nagyobb változáson megy keresztül, mint az elmúlt száz évben. A piaci szereplőknek meg kell birkózniuk ezzel a kihívással. Különösen a bankoknak kell átgondolniuk üzleti modelljüket, és meg kell ragadniuk az innovációk új hulláma által kínált lehetőséget az új ügyfelek megszerzésére, a hatékonyság növelésére és az üzleti modelljük fejlesztésére.

Fennáll azonban a kockázata, hogy a FinTech-jelenség követni fogja a már jól ismert árnyékbankolás mintáját.

A banki tevékenység jövőjéről szólva Hatami (2015) öt forgatókönyvet állít fel.

1. forgatókönyv - A jobb bank. A digitális forradalom lezajlott, és szinte valamennyi ügyfél elsősorban digitális módon tartja a kapcsolatot a bankjával. A hagyományos nagybankok felismerték a lehetőséget, és úgy alakították át üzletmenetüket, hogy megfeleljenek az új digitális elvárásoknak. Átstrukturálták informatikai programjaikat és folyamataikat, bankon belüli és külső partnerkapcsolataikban új projekteket valósítottak meg, és ami a legfontosabb: befektetett eszközökön realizálták a legtöbb hasznot. Sikeresen megtartották a legtöbb ügyfelüket, és átképezték a munkatársaikat, akik így otthonosabban mozognak a digitális világban.

2. forgatókönyv - Az új bank. A hagyományos szereplők nem élték túl a digitális szakadást. Nem feleltek meg ügyfeleik igényeinek, akik csapatostul pártoltak át az újonnan megjelenő bankokhoz. Ezek új, teljes körű szolgáltatást nyújtó intézmények, amelyek megfelelnek a digitális kor kihívásainak. A régi bankokéhoz hasonló szolgáltatásokat nyújtanak, csak gyorsabban, olcsóbban és jobban, mint azok valaha is.

3. forgatókönyv - A megosztott bank. A FinTech-forradalom előrehaladtával nagy számban jelentek meg új vállalkozások, amelyek jobb banki szolgáltatásokat nyújtottak az ügyfeleknek. Nem próbáltak meg univerzális lakossági bankként múködni, csupán bizonyos termékeket kínáltak kiemelkedően jól. Kezdetben pénzforgalmi szolgáltatásokra, hitelekre, megtakarítási termékekre és deviza-

\footnotetext{
${ }^{2}$ Ebben az értelemben a FinTech-szolgáltatások és -termékek réspiaci technológiai megoldásoknak tekinthetők.
} 
kereskedelemre koncentráltak, de szép lassan szerepet vállaltak többek között a jelzálog-hitelezésben, a befektetésekben és a nyugdíj-megtakarításokban.

4. forgatókönyv - A háttérbank. Ebben a forgatókönyvben a bankok az ügyfeleket kiszolgáló üzletkötői részleg háttértámogatását látják el, ők biztosítják a szükséges engedélyeket, a hozzáférést a pénzforgalmi hálózatokhoz és a finanszírozáshoz, és kezelik a betéteket. Fennáll a veszélye, hogy a bankok és a bankfelügyeletek nem tudják teljeskörüen felügyelni a tranzakciókat és a rendszerkockázatot. $A z$ ügyfélkapcsolatok elvesztése és a pénzügyi termékeket közvetítő új platformokra való ráutaltság kedvezőtlen hatással lehet a kockázatkezelési funkciókra és a bevételekre (mivel azokat meg kell osztani az új közvetítőkkel).

5. forgatókönyv - A nem-közvetítő közvetítő bank. Miközben a fogyasztók egyre inkább kiábrándulnak bankjukból, egyre szívesebben használják kedvenc közösségi hálózatukat vagy hardverszolgáltatójukat pénzügyi szolgáltatások vásárlásakor. A pénzforgalommal kezdődött, majd jött a kereskedelmi finanszírozás, a befektetési tanácsadás, a hitelek és a megtakarítási termékek, míg végül a szolgáltatók a bankok összes termékéhez hozzáfértek. Az ügyfelek úgy érezték, hogy ha olyan szolgáltatón keresztül vesznek igénybe szolgáltatást, amelyet szeretnek, és amelyben megbíznak, az garancia arra, hogy nem használják ki őket úgy, ahogy megítélésük szerint a bankok tették (Hatami 2015; BCBS 2018).

A hagyományos bankok számára emberi oldalról is jelentkezik egy kihívás. Hogyan zárják a digitális rést szolgáltatásaikban, és hogyan hozzák be lemaradásukat a FinTech-szolgáltatókhoz képest? A digitális képességek hiánya miatt a vállalatok egymással versengve igyekeznek betölteni a pozíciókat többek között az adatelemzés, az ügyfélélmény-kialakítás, a mesterséges intelligencia és a kiberbiztonság terén. A banki intézmények fele nehezen vagy nagyon nehezen oldja meg ezt a feladatot.

Ugyanennek a kérdéskörnek egy újabb aspektusára világítanak rá a McKinsey éves banki jelentései. 2015-ben jelezték, hogy a FinTech-vállalatok és a digitális platform köré szerveződő cégek erodálják a bankok profitját. Legfrissebb jelentésük szerint azonban a bankok a közelmúltban komoly előrelépéseket tettek. A McKinsey szerint jelentősen csökkentek például a hazautalások, amelyek világszerte fontos alapját képezik a bankok profitjának. Az új cégek, mint például az Azimo, a TransferWise és a TransferGo fejlettebb technológiát fejlesztettek ki, és akár 78 százalékkal olcsóbban kínálják szolgáltatásaikat, mint a hagyományos bankok. A hagyományos szereplők profitja a kiélezett versenyben egyre zsugorodik. Az elmúlt két évben új digitális szereplők és elemzőcégek vetették meg a lábukat a világ piacain, és a bankok profitja valóban alacsonyabb lett, még a jelentős költségcsökkentési intézkedések ellenére is. 
Eközben az új digitális szereplők is változnak. Mivel a befektetésektől eltekintve a legtöbb lakossági üzletágat - legalábbis egyelőre - már teljesen felfedezték, a FinTech-ek a kereskedelmi és vállalati banki tevékenységek felé fordulnak. A McKinsey több mint ezer pénzügyi startupot figyelő Panorama FinTech adatbázisa szerint az egyik leggyorsabban növekvő szegmens a nagyvállalati fizetési megoldások területe. A lakossági bankok és FinTech-ek közötti szövetségek és felvásárlások felfutása határozott üzenetet közvetített: vége a szabadrablásnak. A FinTech-ek a tőkepiacokon és a beruházási banki tevékenységek, főleg a tanácsadás szegmensben is teret nyernek, itt azonban a hangsúly a hagyományos üzleti folyamatok segítésén, és nem lerombolásukon van. A platformcégek valós veszélyt jelentenek, amit kezelni kell. A McKinsey elemzői szerint azonban nem valószínű, hogy ez a globális banki ágazat létét fenyegetné. A banki tevékenységek hosszú múltja alapján feltehetően mindig is szükség lesz pénzügyi közvetítésre, és mindig lehetőség lesz profitot termelni azzal, ha a bank tőkét bocsát mások rendelkezésére, bár elképzelhető, hogy több évbe telik, mire az ágazat ismét nyereséges lesz a gyökeresen megváltozó világgazdaságban. Első lépésként a következő 3-5 évben a bankok számos lehetőséget ragadhatnak meg, hogy visszaszerezzék az őket jogosan megillető ügyfélkapcsolatokat, javítsák termelékenységüket, és digitális eszközök használatával modernizálják múködésüket. Lényegében ugyanazokat a technológiákat kell bevetniük, amelyeket a digitális vállalatok ellenük használnak. Ezek a lépések növelhetik a bevételeket, javíthatják a tőkefelhasználást, és ami a legfontosabb, lefaraghatják a költségeket (McKinsey 2018).

\section{A FinTech az Európai Unióban}

Az Európai Unióban felismerték a digitális technológia fontosságát, és kiemelt stratégiai, gazdasági és a társadalmi jelentőséget tulajdonítanak neki. Az Európai Bizottság deklarálta, hogy az új digitális technológia döntő eleme lesz az EU jövőbeli versenyelőnyének. E fejlődés eredményeként 2015 májusában az Európai Unió egy nagy ívű és átfogó tervnek, a Digitális Egységes Piac Stratégiájának kidolgozásába kezdett, amely 2017-ben befejezésre került. Ennek főbb elemei: a hozzáférés javítása az árukhoz, szolgáltatásokhoz és tartalmakhoz, a digitális hálózatok és szolgáltatások megfelelő jogi kereteinek kialakítása, valamint az adatalapú gazdaság előnyeinek kiaknázása. Becslések szerint a stratégia évi 415 milliárd euróval járulhat hozzá az unió gazdaságához, és több százezer munkahely létrehozását segíti. Ezért aligha szabad alábecsülni az időben történő megvalósítás fontosságát (Európai Bizottság 2017).

A versenyképesebb, innovatív pénzügyi piac stratégiai céljának érdekében 2018 márciusában az Európai Bizottság FinTech Cselekvési Tervet tett közzé, amely a pénzügyi szolgáltatások terén megvalósított technológia-vezérelt innovációkban (FinTech) rejlő lehetőségek kiaknázására koncentrált.

„Az intézkedések célja, hogy Európa a pénzügyi technológiák globális központjává váljon, valamint hogy az európai vállalkozások és befektetők a lehető legnagyobb 
mértékben kihasználhassák azokat az előnyöket, amelyeket az egységes piac kínál e dinamikusan változó területen. Első jelentős intézkedésként a Bizottság egyúttal új szabályokat terjeszt elő a közösségi finanszírozást („,crowdfunding”) biztosító platformok belső piaci növekedésének elősegítésére.

A közzétett cselekvési terv célja, hogy lehetővé tegye a pénzügyi szféra számára a gyorsan fejlődő új technológiák, például a blokkláncok, a mesterséges intelligencia és a felhőszolgáltatások alkalmazását. A terv másik törekvése a piacok biztonságának növelése és a piaci hozzáférés megkönnyítése az új szereplők számára. Ez közös érdeke a fogyasztóknak, a befektetőknek, a bankoknak és az új piaci szereplőknek egyaránt. A Bizottság emellett páneurópai címkét javasol bevezetni a közösségi finanszírozási platformok számára. Ennek segítségével az a platform, amelyet az egyik tagállamban már engedélyeztek, az összes többi tagállamban is működhet majd.

A cselekvési terv a tőkepiaci unió és a fogyasztói pénzügyi szolgáltatások valóban egységes piacának kialakítására irányuló európai bizottsági törekvések része, de részét képezi a digitális egységes piac létrehozását célzó erőfeszítéseknek is. Az intézkedések révén a Bizottság az uniós szabályokat jövőorientálttá kívánja tenni és hozzá kívánja igazítani a gyors technológiai fejlődés újdonságaihoz." (Európai Bizottság 2018).

Az Európai Uniónak a FinTech-ek támogatására és ösztönzésére vonatkozó komoly szándékát az alábbi adatok is alátámasztják, amelyekből kitűnik a 2017 utáni, azaz a digitális egységes piac koncepciójának elfogadását követő erőteljes növekedés (3. ábra).

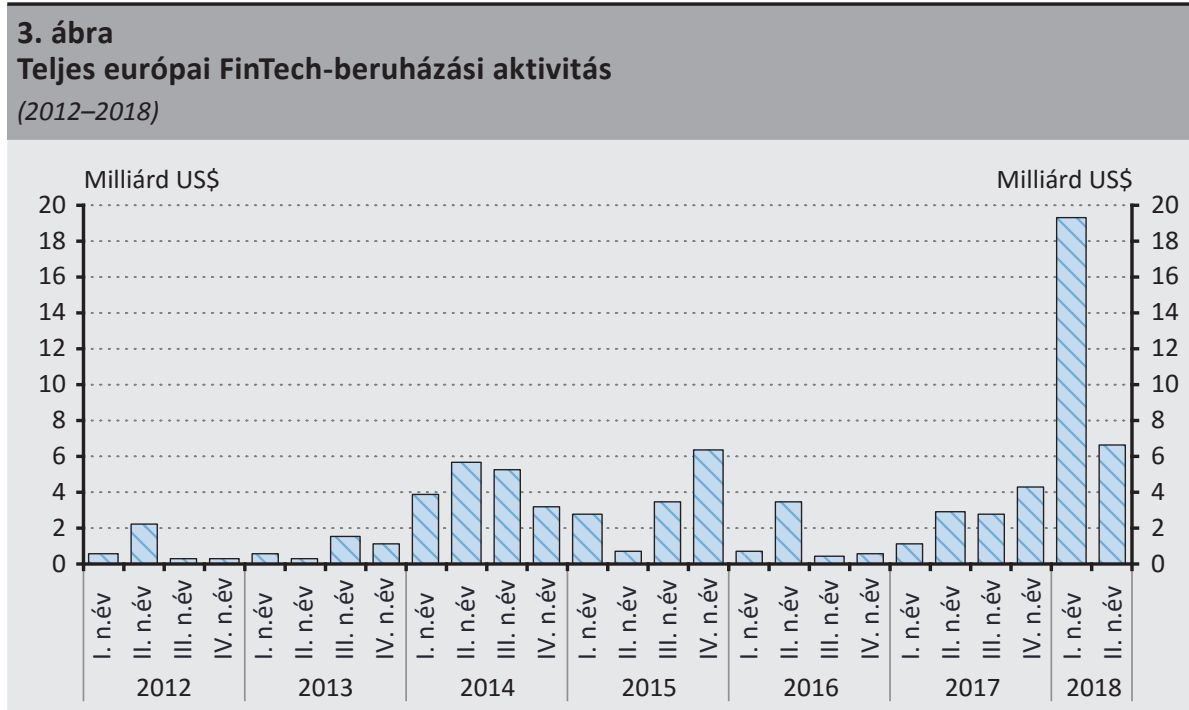

Forrás: KPMG $(2018,34$. o.) 
A FinTech-kérdéskör Európán belüli fontosságát jól jelzi a következő fejlemény: az uniós FinTech Cselekvési Terv közzétételét követő napon, 2018 márciusában az Európai Bankhatóság (EBH) „Designing a Regulatory and Supervisory Roadmap for FinTech" (A szabályozói és felügyeleti FinTech-munkaterv kialakítása) címen kiadta FinTech-munkatervét.

$\mathrm{Az}$ EBH munkaterve fontos összefoglalása a hagyományos bankok és FinTech startupok által nyújtott szolgáltatásokhoz szükséges és tervezett szabályozói megközelítésnek.

\begin{abstract}
„A jelenlegi szabályozói megközelítések többsége a két szélsőség, a »megengedő« és a »szabályozó és tiltó« megoldás között helyezkedik el. Általában három összetevőn alapulnak: az innováció nyomon követése, a közérdeket érintő kockázatok értékelése (mikroprudenciális kérdések, pénzügyi stabilitás, fogyasztóvédelem és piaci integritás), valamint a fennálló szabályok szelektív alkalmazása, szükség esetén az innovációhoz való igazítása érdekében alakítva rajtuk.
\end{abstract}

Általánosságban ez a pragmatikus hozzáállás egy többszintű szabályozói struktúra köré szerveződik, a vállalatok, ügyfeleik, a pénzügyi szektor és a gazdaság egészének kockázatai szerint differenciált szabályozói követelményekkel. Elvben az „azonos kockázat, azonos szabályok" elvárása érvényesüljön."

A dokumentum egy másik fontos megállapítását idézve: „Habár a FinTech-vállalkozások kínálhatnak bankszerű termékeket, és versenyezhetnek bankokkal ugyanazokért az ügyfelekért, ez még nem feltétlenül jelenti azt, hogy banki engedélyt kell kapniuk és bankként kell őket szabályozni és felügyelni. Fontos megkülönböztetni a banki tevékenység lényegét jelentő szolgáltatásokat, amelyeket éppen ezért kizárólag az engedéllyel rendelkező bankok kínálhatnak, valamint azokat a kiegészítő szolgáltatásokat, amelyeket önmagukban más közvetítők is nyújthatnak, versenyre kelve a szabályozott bankokkal." Az EBH FinTech-munkaterve bemutatja az EBH prioritásait 2018/2019-re, és indikatív ütemtervet kínál az adott feladatok elvégzéséhez. A prioritások a következők:

- a szabályozói terület (regulatory perimeter) feltérképezése, beleértve a jelenleg érvényben lévő, FinTech-cégeket érintő engedélyezési eljárásokat, valamint az innovációs platform (innovation hub), illetve a szabályozói tesztkörnyezetek (sandboxok) elemzését a legjobb gyakorlatok halmazának meghatározásához az egységesség erősítése és a felügyeleti együttmúködés hatékonyabbá tétele céljából;

- az újonnan kialakuló tendenciák nyomon követése és a jelenleg aktív intézmények üzleti modelljeire gyakorolt hatásuknak elemzése, valamint a FinTech használatából eredő prudenciális kockázatok és lehetőségek vizsgálata;

- a kiberbiztonság vizsgálatával összefüggő legjobb felügyeleti gyakorlatok népszerüsítése és a kiberveszély tesztelésére szolgáló egységes keretrendszer támogatása; 
- a FinTech-tevékenységből eredő fogyasztói problémák kezelése, amelyek a FinTech-cégek nem egyértelműen szabályozott státuszából és a fogyasztók tájékoztatásának hiányosságaiból erednek; a potenciális nemzeti határok gátjának lebontása, amely megakadályozza a FinTech-cégek szolgáltatásainak bővítését és a virtuális pénznemekre vonatkozó jelenlegi szabályozási keret alkalmazását az egységes piacon;

- a szabályozott FinTech-cégekhez, technológiaszolgáltatókhoz és FinTech-megoldásokhoz köthető pénzmosás vagy terrorizmusfinanszírozás kockázatának azonosítása és felmérése (EBH 2018, Enria 2018).

Egy tanulmányában³ a Bázeli Bizottság Pénzügyi Stabilitási Tanácsa 2018 februárjában összefoglalta, hogy „hogyan hathat a pénzügyi szolgáltatások, azaz a »FinTech« terén végbement technológia-vezérelt innováció a banki ágazatra és a felügyeleti hatóságok tevékenységére rövid és középtávon" (BCBS 2018). A kimerítő elemzés kitűnően leírja a pénzügyi technológiai fejlesztéseket és a jelenleg ismert FinTech üzleti modelleket. „Ebben a környezetben a mostani megfigyelések alapján a banki ágazatot a múltban ugyan már többször is érintette az innováció, a segítő technológiák gyors alkalmazása és az új üzleti modellek megjelenése egyre nagyobb kihívás elé állítja a hagyományos bankokat, szinte az összes tárgyalt banki ágazati forgatókönyvben."

A Bázeli Bizottság összefoglalta a javasolt banki felügyeleti megközelítés tíz legfontosabb lehetséges következményét a hagyományos bankok és a FinTech-szolgáltatók kapcsolataira:

1. a biztonság, a megbízhatóság és a magas szintű megfelelőségi követelmények kialakítása a bankszektor előnyös innovációinak akadályozása nélkül;

2. a FinTech-fejlesztésekkel kapcsolatos föbb banki kockázatok, többek között stratégiai/jövedelmezőségi kockázatok, működési, kiber- és megfelelési kockázatok;

3. az innovatív segítő technológiák alkalmazásának bankokra kifejtett hatása;

4. a harmadik felek kiszervezésen, illetve partneri kapcsolatokon keresztül történő egyre gyakoribb használatának a bankokra kifejtett hatása;

5. szektorközi együttműködés a bankfelügyeletek és egyéb érintett hatóságok között;

6. a bankfelügyeletek nemzetközi együttműködése;

7. a felügyeleti eszköztár adaptálása;

8. az innovatív technológiák alkalmazásának lehetősége a felügyeleti hatóságok számára („suptech”);

3 "Sound Practices: On the implications of FinTech developments for banks and bank supervisors" BCBS (2018) 
9. a fennálló szabályozási keretrendszerek fontossága az új innovatív üzleti modellek szempontjából;

10. a FinTech innovációját megkönnyítő szabályozási kezdeményezések legfontosabb jellemzői.

A legfrissebb fejlemények tükrében nyilvánvaló, hogy az uniós döntéshozók tisztában vannak a pénzügyi technológia fejlesztésének fontosságával és globális versenyképességi hatásával. Az erőfeszítések középpontjában az Európai Monetáris Unió és az Európai Tőkepiaci Unió fejlesztésének támogatása áll. Egyfelől megerősítik, hogy támogatni kell a digitális alkalmazásokat, a FinTech-szolgáltatások elérhetőségét, másfelől pedig a felügyeleti kockázatértékelés és fogyasztóvédelem javítását és a vonatkozó jogszabályi keretek megszilárdítását sürgetik. Erősen hangsúlyozzák, hogy a hagyományos bankok és a FinTech (TPP) szolgáltatók számára egyenlő feltételeket kell biztosítani.

Minden bizonnyal a pontos definíció hiányára vezethető vissza az Európai Központi Bank jelenlegi álláspontja, amelynek értelmében a FinTech-szolgáltatások szabályozásának és felügyeletének egyelőre nemzeti hatáskörben kell maradnia. A következő kihívás az, hogy hogyan biztosítsák az egyenlő versenyfeltételeket a hagyományos bankok és a FinTech-szolgáltatók számára. Nem könnyű kiegyensúlyozott megoldást találni. A FinTech startupok alapításához kevesebb tőke kell, az ügyfélszerzés olcsó, a szabályozás és a felügyelet pedig engedékeny vagy nincs is. A hagyományos bankok súlyos költségvetési megszorítások árán csak nemrég hagyták maguk mögött a nemzetközi pénzügyi válság következményeit, ezért kevesebb forrást tudtak fordítani a digitális fejlesztésekre. Ezenkívül merev és néhány esetben túlszabályozott környezetben múködnek, szigorú értékelési kritériumoknak kell megfelelniük. Másfelől azonban a FinTech-ek által jelentett kihívás arra ösztönzi a bankokat, hogy behozzák a lemaradásukat, és pénzügyi és digitális technológiai beruházásokat hajtsanak végre. Eldördült a startpisztoly, és legalábbis bizakodunk, hogy végül mindenki jól jár, és a folyamat magasabb színvonalú szolgáltatásokat eredményez.

Két évszázaddal ezelőtt, Benjamin Franklin korában még két dolog volt biztos, a halál és az adók. Mára már a halál az egyedüli elkerülhetetlen. A digitális gazdaság előretörésével egyre több gazdasági érték származik immateriális javakból, például a digitális platformokból, a közösségi médiából és a közösségi gazdaságból gyűjtött adatokból. Mivel manapság könnyedén át lehet helyezni a vállalatok székhelyét egyik országból a másikba, az országok még nehezebben szedik be az adókat. A közkiadásoknak ugyanakkor a globalizáció és a digitális technológiák korában leszakadók szükségleteinek fedezéséhez valószínűleg növekedniük kell.

Lehet azonban, hogy ez megváltozik. Egy napjainkban egyre nagyobb népszerúségnek örvendő javaslat szerint az ingyenes digitális szolgáltatásokat kínáló vállalatok másképp adóznának, így immateriális értékük adózási szempontból ugyanolyan 
elbírálás alá esne, mint a gyártók és hagyományos szolgáltatók által létrehozott kézzelfogható értékek.

Az illetékes uniós döntéshozók ezenkívül annak a jelentőségét is felismerték, hogy a digitális (FinTech) fejlesztéseket adózási szempontból is alaposan ellenőrizni kell. Az uniós Digitális Egységes Piac kialakítása során az Európai Bizottság javaslatot tett a jelentős digitális jelenlét társasági adózási szabályainak lefektetéséről szóló tanácsi irányelvre. A Bizottság javaslata szerint „a digitális gazdaság átalakítja azt, ahogyan kommunikálunk, fogyasztunk és üzleti tevékenységet folytatunk. A digitális vállalatok sokkal gyorsabban növekednek, mint a gazdaság egésze, és ez a tendencia várhatóan folytatódik." (Európai Bizottság 2018).

A digitalizáció azonban az üzleti modellek változásával a nemzetközi adórendszert is kihívás elé állítja. A politikai döntéshozók még dolgoznak az igazságos és eredményes adóztatást biztosító megoldásokon, miközben gyorsul a gazdaság digitális átalakulása, és a fennálló társaságiadó-szabályok elavultak ahhoz, hogy lépést tartsanak ezekkel a változásokkal.

A jelenlegi társaságiadó-szabályok alapelve, hogy a profitot ott kell megadóztatni, ahol az érték előállításra kerül. Ezeket azonban túlnyomórészt a 20. század elején, a hagyományos vállalkozásokra dolgozták ki, a „tégla és beton helyének” elve alapján, azonban azt, hogy egy adott ország az adózási jogát mire alapozza („adózás helye”), illetve hogy a vállalati bevételek mekkora részére jogosult („adó mértéke”) alapvetően az adott országban meglévő fizikai jelenléten alapul, és nem tükrözi az adott joghatóságban felhasználói részvétellel létrehozott értéket.

A javaslat célja a tagállamok fennálló társaságiadó-rendszereinek átfogó kezelésével kísérletet tenni a digitális gazdaság által felvetett problémák orvoslására. Az uniós digitális tevékenységek adóztatására olyan egységes rendszert vezet be, amely kellően figyelembe veszi a digitális gazdaság tulajdonságait. Először is a nem fizikai kereskedelmi jelenlét esetében a javaslat meghatározza az országhatárokon átívelő tevékenységet folytató digitális vállalatok adózási alapját (a továbbiakban: „jelentős digitális jelenlét"). Erre a jelentős digitális jelenlétre új mutatókat kell kidolgozni, hogy kialakulhasson és védelmet élvezhessen a tagállamok új digitalizált üzleti modellekkel kapcsolatos adóztatási joga. Másodszor a javaslat megfogalmazza azokat az alapelveket, amelyek mentén a profit a digitális vállalkozásokhoz rendelhető. Ezek az elvek jobban megfelelnek majd a digitális üzleti modelleknek, amelyek értéke alapvetően az immateriális javak értékére támaszkodik. Az irányelv a tagállamok nemzeti jogszabályaiba történő átültetését követően az unión belüli határon átnyúló digitális tevékenységekre vonatkozik majd, még akkor is, ha a vonatkozó kettős adóztatás elkerüléséről szóló egyezményt a tagállamok nem módosították ennek megfelelően. Ez az uniós irányelv rögtön a hatálybalépését követően kedvező hatással lesz a hagyományos bankok és a FinTech startupok között kívánatos egyenlő feltételek kialakítására. 


\section{A FinTech jelenléte Kínában}

„Globális szinten fokozódik a verseny a FinTech világban. Mint az innovatív piacok esetében olyan gyakran előfordul, a siker kulcsa a nagy belföldi piac, amelynek révén a sikeres vállalatok olyan méretüre nőhetnek, amilyennel már globális vezető szerepre is pályázhatnak. Hosszú távon az európai FinTech-szereplők jelentős hátrányba kerülhetnek az egyesült államokbeli és kínai versenytársaikkal szemben, ha az európai piacok továbbra is szegmentáltak maradnak a nemzeti határok mentén, mert a helyi hatóságok eltérő helyi szabályokkal múködnek és koordinálatlan tevékenységet folytatnak" (Enria 2018).

A kínai tapasztalatokról szóló jelen fejezetben három szempontból vizsgáljuk a FinTech jelenségét: a kínai kormány, a People's Bank of China (a Kínai Központi Bank) és a Kínai Bankszabályozási Bizottság (CBRC) ${ }^{4}$, valamint a kínai kereskedelmi bankok szemszögéből.

A rövid áttekintés érdekében Kínának a FinTech-hez való viszonyára utalunk, amelyet kiváló pénzügyi szakemberek mutattak be az AFCA „Ázsiai és Közép-Kelet-Európai Pénzügyi Csúcstalálkozó - Új fejezet Ázsia és Európa pénzügyi együttmúködésében" című konferenciáján 2017 novemberében, Budapesten. A kínai FinTech-szektor gyors ütemben fejlődik, és sok tekintetben globális vezető szerepet tölt be. Az ország digitális fizetései a globális volumen közel felét teszik ki, és az online személyközi (P2P) hitelezés a globális érték háromnegyedére rúg. Kína FinTech-szektora kulcsfontosságú válaszúthoz érkezett. A kínai kormány FinTech-hez való viszonya egyre bonyolultabbá vált, ahogy a P2P-platformok körül sűrűsödtek a kockázatok, a feketegazdaságba történő forrásbevonások száma megnövekedett és a finanszírozási tevékenység megugrott. A hatóságok általánosságban néhány közelmúltbeli szigorító intézkedés ellenére továbbra is támogatók (Hu et al. 2016; PWC China 2017).

Az internetes finanszírozással kapcsolatban Li Ko-csiang miniszterelnök fontos gondolatokat fogalmazott meg: „A megfelelő szabályozói együttmúködéssel és felügyeleti mechanizmusokkal ösztönözni fogjuk, hogy az internetes finanszírozás egészséges fejlődési pályára álljon” és „azon leszünk, hogy a szabályozásnak megfelelően fejlődjön". A kínai kormány szabad kezet adott a szereplőknek a kísérletezésre. A digitális tevékenységek és szereplők engedékeny, úgynevezett „könnyű érintésü" - pontosabban megkésett - „későn megérintett” szabályozása bátorította a vállalkozási hajlandóságot és a kísérletezési kedvet Kínában. Mivel a szabályozók válaszai csak követni tudták a piaci fejleményeket, a kínai internetes óriások viszonylag szabadon tesztelhették és dobhatták piacra a termékeket és szolgáltatásokat, és nőhettek kritikus tömegüre. Például a szabályozó hatóságok csak 11 év után szabtak felső korlátot azt követően, hogy az Alipay 2005-ben bevezette az online pénzát-

${ }^{4} 2018$ áprilisától a CBRC helyett már a CBIRC múködik, a bankok mellett a biztosítókra is kiterjed a tevékenységük. 
utalásokat. A kínai szabályozó hatóság csak öt évvel azután dolgozott ki hivatalos sztenderdet a kezelési követelményekről, hogy az Alipay elterjesztette a vonalkód alapú fizetési megoldásokat (McKinsey 2017).

A kereskedelmi bankokról szólva nézzük meg néhány nagyobb kínai pénzintézet véleményét. Liu Csiang, a Bank of China alelnöke amellett érvelt, hogy át kell venni a vezető szerepet a technológiai innovációkban, és javítani kell a pénzügyi szolgáltatások hatékonyságát. A FinTech javíthatja a reálgazdaság finanszírozásának minőségét. A FinTech-fejlesztések gazdagították a pénzügyi szolgáltatások tartalmát és kibővítették a piacot. Az új technológiák kombinációja a tőkével és a piaccal rendkívüli erejű lehet. Minden banknak jelentősen fokoznia kell az innovációját és együttmúködését a technológia terén, elő kell segítenie a banki szolgáltatások hatékonyságának átalakítását és korszerűsítését. Mindenki láthatja, hogy a technológiai fejlődés folyamatosan építi le az információs aszimmetriát, aminek hatalmas jelentősége van a pénzügyi fejlődés szempontjából. A FinTech-nek számos értelmezése, jelentése van, és a végeláthatatlan technológiai haladáson belül a pénzügyi fejlődés fő irányává válik.

Míg a hagyományos és nem hagyományos digitális pénzügyi szolgáltatások kimagasló növekedését az elmúlt években a technológiai innováció, a haladás, a gyorsan változó fogyasztói magatartás és a finanszírozási formákhoz való alkalmazkodás hajtotta, a kínai szabályozási környezet is jó táptalaja volt a növekedésnek. Ezt az adatok is alátámasztják (4. ábra).

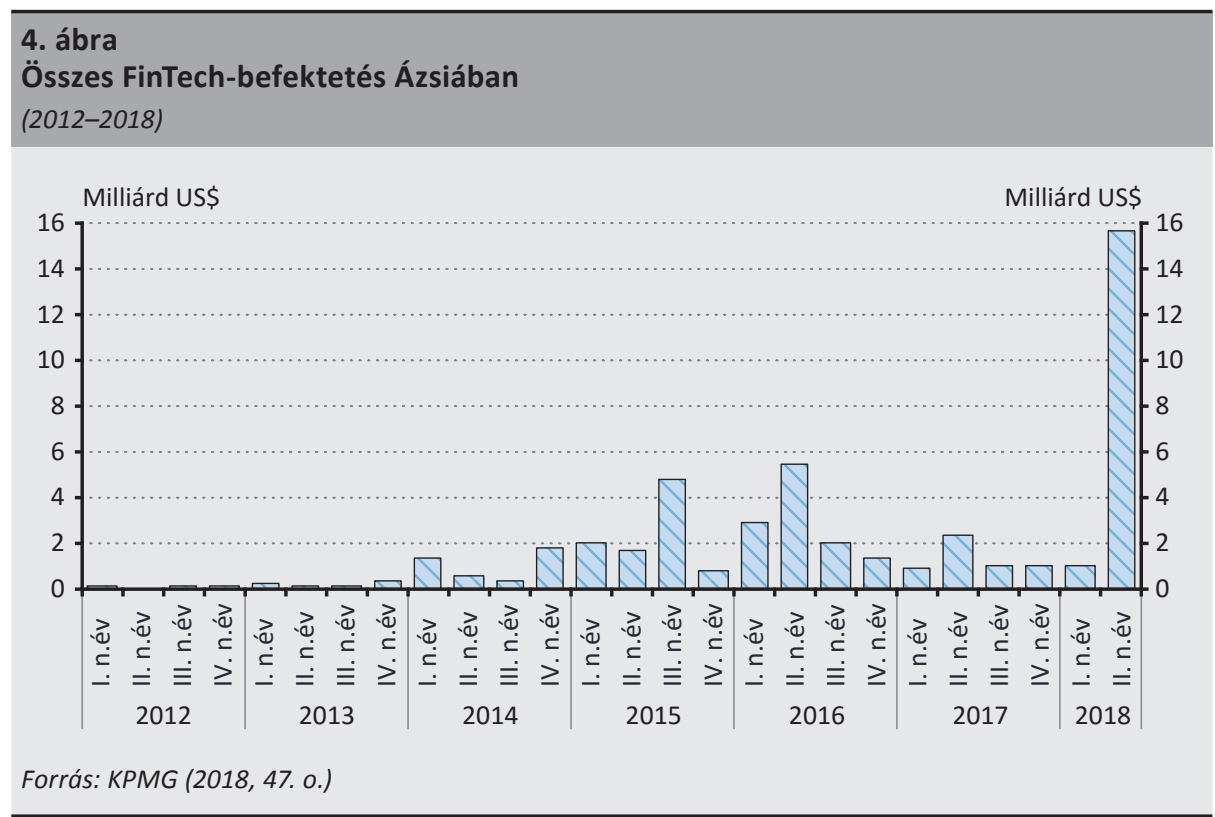


Huan Yi, a China Construction Bank ügyvezető alelnöke „Pénzügyi technológia és stratégiai átalakulás a kínai bankszektorban” címmel tartott előadást. Elmondta, hogy Kínában az internetes finanszírozás gyors fejlődése a bankszektor zsugorodása helyett verseny- és együttmúködésbeli fejlődést eredményezett a kétirányú interakciók és az egymást kiegészítő előnyök révén. A technikai területek előretörése és kiforrottsága szilárd alapot biztosított a banki ágazat technológia-vezérelt átalakulásához. Yi hozzátette, hogy a pénzügyi technológia közvetlenebbül, erőteljesebben és eredményesebben befolyásolja az átalakulást. Ahogy várható volt, a pénzügyi technológia fejlődése először a fizikai korlátokat bontotta le hatékonyan, és a banki csatornák integrációját támogatta. Ezen túlmenően a pénzügyi technológia a banki üzleti modellek reformját is előmozdította, és fokozatosan népszerúsítette a forgatókönyveken és platformokon alapuló szolgáltatási módokat. Gazdagította továbbá a kockázati kontroll módszereit, eredményesebbé téve a kockázatkezelést. Yi úgy folytatta, hogy mivel a pénzügyi technológiának vannak előnyei, Kína kidolgozhatna alapvető technológiákat és meghatározhatna szabadalmi standardokat. A kínai kereskedelmi bankok és néhány nagy internetes vállalat nemzetközi összehasonlításban is élen jár a pénzügyi technológiai gyakorlatok alkalmazása terén. Ezt az előnyt kihasználva kellene a kapcsolódó technológiákat integrálniuk és sajátjukként szabadalmaztatniuk, majd ezt kihasználva átalakítaniuk a nemzetközi pénzügyi ágazat folyamatait, hogy új sztenderdeket fogalmazzanak meg és fokozzák a kínai banki ágazat alapvető versenyképességét (Kerényi - Müller 2018).

A CBRC, a Kínai Bankszabályozási Bizottság célja a szabályozás és a felügyelet erősítése. „A keretrendszer alapján a Digital Finance szabályozásával kapcsolatos alapelvek a »tolerálni, megengedni, ösztönözni, irányítani és sztenderdizálni«, a kapcsolódó felügyeleti elvárások pedig az »átfogó, megfelelő időben történő, szakmai és hatékony« jellemzőkkel foglalhatóak össze” (Varga 2017:134).

2018-ban a Budapesti Renminbi Kezdeményezés Konferencián ${ }^{5}$ Ren Zhe, a People's Bank of China képviselője, a kínai FinTech-szabályozás közelmúltbeli fejleményeiről beszélt. Aláhúzta, hogy az internetes finanszírozás tág fogalom, és az internetes fizetések, a digitális valuták és a digitális infrastruktúra más és más megközelítést igényelnek. Változtatni kell a szabályozói és felügyeleti követelményeken, valamint ezzel összefüggésben a hagyományos és az új szereplők üzleti ösztönzésén is. Véleménye szerint „a FinTech-tevékenységeket illetően nincs egységes álláspont; a FinTech-ökoszisztéma javítása csökkenthet bizonyos jelentős kockázatokat; a szabályozás hatékonyságát tökéletesítő új ötleteket és megközelítéseket kell kidolgozni”. Zsen Csö a FinTech-tevékenységekre vonatkozó egységes szabályozói megközelítés hiányában az önmérséklet és önszabályozás jelentőségét hangsúlyozta.

\footnotetext{
${ }^{5}$ További információk az eseményről: https://www.mnb.hu/sajtoszoba/sajtokozlemenyek/2018-evisajtokozlemenyek/budapest-renminbi-kezdemenyezes-2018-konferencia-a-jegybankban és (Mészáros 2018).
} 


\section{A FinTech Magyarországon}

A FinTech fejlődéséhez való uniós és kínai megközelítések áttekintése után most röviden összefoglaljuk a magyar helyzetet. ${ }^{6}$

Természetesen a magyar FinTech-megközelítés közelebb áll az európai unióshoz, de még inkább az euroövezetbelihez, vannak azonban országspecifikus jellemzői. A globális pénzügyi válság a magyar pénzügyi szektort érzékenyen érintette: a hitelezési aktivitás és a jövedelmezőség csökkent, a nem teljesítő hitelek aránya (NPL-ráta) megugrott, a devizában denominált lakossági hitelek óriási terhet jelentettek. Miután a bankok költségcsökkentő intézkedéseket vezettek be, a bankszektor visszatérhetett az informatikai és egyéb szolgáltatások megszokott fejlesztéséhez. A digitális innovációk és a FinTech-megoldások növekedése az elmúlt három vagy négy évben kezdődött el. Habár a bankszektorban viszonylag magas, mintegy 50 százalékos a külföldi tulajdon aránya, a legtöbb FinTech-fejlesztést a magyar leánybankok a saját kezdeményezéseik alapján végzik, s nem csupán változatlan formában implementálják az anyabankok megoldásait. Szintén különleges, bár nem egyedi jelenség, hogy a Magyar Nemzeti Bank (MNB) Magyarország központi bankjaként szabályozói és felügyeleti hatáskörrel egyaránt rendelkezik.

Ezzel a háttérrel az MNB kiemelt ügyként tekint a FinTech szabályozására. Amikor a FinTech szabályozásának ötlete először vetődött fel az MNB-ben, első lépésben a világ más központi bankjainak legjobb gyakorlatait vették górcső alá. Az MNB olyannyira fontosnak tartja a FinTech-fejlődés támogatását, hogy „egy olyan innovációs központot (multilaterális konzultációs platformot) is létrehoztak, amely a kezdeti fázisban lévő FinTech startupoknak, vagy akár a már piacon levő szereplőknek segít eligazodni szabályozási kérdésekben, és a piaccal együttmúködve segíti elő a jó ötletek üzleti megvalósítását" (Thurzó 2017).

A FinTech-újításokat fejlesztő és kínáló piaci szereplők magatartásának és javaslatainak felmérésére az MNB specifikus kérdőivet állított össze. A felmérés szerint „a bankok úgy látják, hogy továbbra is meghatározó szerepük lesz a pénzügyi közvetítésben. Ugyanakkor a FinTech-cégek döntő többsége rendszeres kapcsolatban áll bankokkal, vagy felkeresett már bankot az elindulása óta. Ez annak köszönhető, hogy a bankok az anyagi támogatás mellett sokszor képesek a múködésük során felhalmozott tudás megosztásával is segítséget nyújtani. Az újonnan alakult FinTech-cégek számára a hosszú időre visszatekintő banki adathalmazhoz való hozzáférés létfontosságú múködési feltételeik kialakításában, ezen felül a bankok részleteiben ismerik az iparágra vonatkozó részletes jogszabályi kötelezettségeket. A bankok rendszerszintű gondolkodásmódja vélhetően a lehetséges múködési és pénzügyi

\footnotetext{
${ }^{6}$ Ez a fejezet a Magyar Nemzeti Bank FinTech-innovációkkal és lehetséges szabályozásukkal kapcsolatos piaci felmérésének eredményeit közlő konzultációs anyagán (MNB 2017; Fáykiss et al. 2018) és a szerzők által az MNB képviselőivel készített interjún alapul.
} 
kockázatokról is pontosabb iránymutatást tud adni. A hagyományos szereplők főként partnerségi megoldásokban gondolkodnak a FinTech-innovációk kapcsán. A banki motivációt a hatékony megoldások mielőbbi megismerése és adaptálása adja, emellett a FinTech-cégek beállítottságában tapasztalt rugalmasság és flexibilitás, illetve a gyors döntéshozatal képessége elősegítheti a bankrendszer technológiai fejlődését. Az együttmúködés meghatározó eleme a hosszabb távon fenntartható üzleti modell biztosítása. A bankok úgy vélik, együttműködések és inkubációs programok kialakításával a hosszú távú gondolkodás elősegítése megvalósítható, aminek következtében idővel az innovációk a hagyományos bankrendszer részévé válhatnak" (MNB 2017).

A nemrégiben létrehozott MNB Innovation Hub (Pénzügyi Innovációs Platform) a valójában felmerülő jogi akadályok azonosításában és az innovatív ötletek megvalósíthatóságának javításában segít (Fáykiss et al. 2018). Az online platform kapcsolatot teremt a szabályozó és felügyeleti hatóság, valamint az innovatív belföldi intézmények (pl. FinTech-cégek, bankok, biztosítók) között, és támogatja a nemzetközi jó gyakorlatok megismerését az alábbiakkal:

- Információs tárház

- Kommunikációs központ

- Szabályozói támogató platform

- Nemzetközi kooperációs platform

„A Regulatory Sandbox-szal kapcsolatosan azonban bizonytalanság is tapasztalható, az intézmények 65 százaléka nem döntötte el részvételi szándékát, viszont a válaszadók 29 százaléka rövid időn belül hajlandó és képes is lenne megkezdeni valamilyen innovatív termékkel vagy szolgáltatással egy tesztelési fázist. A FinTech-cégek jelentős része már együttműködésben áll a hagyományos banki szereplőkkel. A FinTech-cégek jellemzően nem érzékelnek elutasítást a bankok részéről. A piaci konzultáció az együttmúködés különböző formáit erősítette meg. Az MNB mintájába bekerülő hazai cégek több mint egyharmada jelezte, hogy bankkal partnerségi kapcsolatban áll: banki inkubációs program résztvevője, vagy megbízási szerződéssel, külső szolgáltatóként beszállít banknak. Viszonylag ritka, hogy a bankok a FinTech tudását felvásárlással megszerezzék. A FinTech-cégek részéről a nyitottság jellemzően fenn fog maradni, a minta mintegy fele tervez a jövőben is további együttmúködést. Az együttmúködés teljes elutasítását összesen három cég jelezte" (MNB 2017).

Végezetül az is nagyon érdekes, hogy hogyan viszonyulnak a hagyományos bankok a FinTech magyarországi fejlődéséhez. A Magyar Bankszövetség elnöke a következőképpen foglalta össze álláspontját a digitális világ és a FinTech jelentette kihívások- 
ról: „A digitalizáció a bankszektor számára egy hatalmas kihívást, megújulást jelent. A 20-30 évesek nem fognak fiókba járni, sokan már most sem járnak, és minden tranzakciót mobiltelefonon és neten hajtanak végre. Megváltoznak az ügyfélszokások, a fiók jelentősége csökken, a technológia jelentősége pedig megnő. Számos bank számára valós veszély, hogy szerepüket át fogják venni új szereplők, például fizetési szolgáltatók. Ezt a szabályozók a világon mindenhol figyelemmel kísérik, és ha ők hitelezni akarnak majd, és ugyanazokat a szabályokat, tőkekövetelményeket várják el tőlük, mint a bankoktól, akkor a bankok le fogják őket győzni a versenyben. Veszély van, de a bankok meg fogják tanulni, hogy az új technológiákat hogyan kell használni, mintsem új szereplők vennék el a kenyerüket. A bankok komoly integrációra készülhetnek a FinTech-cégekkel" (Patai 2018). Egyelőre az ügyfelek szempontjából is kedvezőnek mondható, hogy a hagyományos magyarországi bankok nem viszonyulnak ellenségesen a FinTech startupokhoz.

\section{6. Összefoglalás és következtetések}

A 21. század eleje óta részesei vagyunk a digitális átalakulásnak, a digitális technológiához kapcsolódó olyan változásoknak, amelyek a társadalom és a gazdaság valamennyi területére hatással vannak. A negyedik ipari forradalom már elkezdődött és üteme egyre gyorsabb. A pénzügyi technológia a pénzügyi szolgáltatások egyik leginnovatívabb, egyre fontosabb és potenciálisan leggyorsabb változását képviseli, amely forradalmasítja a pénzügyi szolgáltató vállalatok múködését, és átalakítja a hitel- és részvénypiacokat, a pénzforgalmat, a hitelbírálatokat, a szabályozói megfelelést, a személyi pénzügyeket és a pénzügyi szolgáltatások számos egyéb aspektusát. A folyamat jobb megértése érdekében röviden összehasonlítottuk a három korábbi ipari forradalom tanulságait. Látunk hasonlóságokat, hiszen a forradalmak hirtelen kezdődnek, általában pozitív és nagy horderejű változásokkal járnak, de vannak romboló hatásaik is. Kezdetben nehéz megjósolni kifutásukat, előre megmondani, hogy minek lesz tartósan kedvező hatása, felmérni a potenciális kockázatokat és azok kezelését.

Napjainkban és korunkban a bankszektor egyik legnagyobb kihívása a szabályozó és felügyeleti hatóságok szempontjából a pénzügyi szolgáltatások digitális átalakulása. Ebben az összefüggésben a hagyományos pénzügyi közvetítés jövője, valamint a hagyományos bankok és a FinTech startupok közötti kapcsolat egyaránt érdemi kérdés. Ezek a fejlemények és a piacon megjelenő új szereplők felvetik a potenciális kockázatok kérdését, azaz hogyan kellene változtatni a szabályozáson és a felügyeleten, továbbá hogy a tisztességes verseny és az egyenlő versenyfeltételek megvalósíthatók és fenntarthatók-e. 
A FinTech-jelenség vizsgálatakor az első feladat a tevékenység pontos definíciójának meghatározása. Egyértelmúen látszik, hogy a pénzügyi technológiáknak nem azért nincs széles körben elfogadott definíciójuk, mert a szabályozók nem rendelkeznek elég aktuális ismerettel vagy információval, hanem mert annyira gyors a fejlődés, hogy a felügyeleti hatóságok és központi bankok csak követni tudják a gyorsan változó eseményeket. A definíció elégtelen volta az általunk vizsgált valamennyi területre jellemző. A legszélesebb körben használt definíció a Pénzügyi Stabilitási Tanács munkaanyagként kiadott definíciója a FinTech-re vonatkozóan, amely szerint jelentése „technológiavezérelt pénzügyi innováció, amely olyan új üzleti modelleket, alkalmazásokat, folyamatokat vagy termékeket eredményezhet, amelyek jelentős hatással lehetnek a pénzügyi piacokra és intézményekre, valamint a pénzügyi szolgáltatásokra”. Ezt a tág, „pragmatikus” definíciót tekintik a szabályozás alapjának.

A megengedő, tág definíció nem következmények nélküli. Mivel a definíció nem azonosítja egyértelműen a FinTech-szolgáltatások tartalmát és körét, megnehezíti a felügyeleti ellenőrzések határait kijelölő jogszabályi keretek, valamint a hagyományos bankok és a FinTech-vállalatok közötti verseny egyenlő feltételeinek biztosítását. Ha a banki szereplőkre szigorú szabályozási követelmények érvényesek, a FinTech-vállalkozások jogosulatlan versenyelőnyt élveznek, és a részletes szabályok hiánya az érintettek számára is kockázatokat hordoz. Ha egy kiforratlan megoldás túl korán kerül a piacra, mind az ügyfelek, mind a hitelezők számára nem várt veszteségeket okozhat. A túlzottan megengedő szabályozói hozzáállás a pénzügyi közvetítést olyan szegmensbe kényszerítheti, amelyben a szabályozó hatóságoknak csupán korlátozott ráhatásuk lehet.

A kronologikus és globális áttekintés után vizsgálatunkat három földrajzi területre koncentráltuk: az Európai Unióra, Kínára és Magyarországra. Megítélésünk szerint az első kettő hozzájárult ahhoz, hogy azonosítsuk a pénzügyi digitális fejlődés globális irányát, a megközelítések hasonlóságait és különbségeit, valamint végső soron azt is, hogy Magyarország hol tart ebben a folyamatban.

Az Európai Unióban felismerték a digitális technológia fontosságát, és kiemelt stratégiai, gazdasági és a társadalmi jelentőséget tulajdonítanak neki. Az Európai Bizottság kijelentette, hogy az új digitális technológia döntő eleme lesz az EU jövőbeli versenyelőnyének. Az Európai Unió ezért dolgozta ki nagy ívú és átfogó stratégiáját a Digitális Egységes Piac megvalósítása érdekében, amit nem sokkal később, 2018-ban a FinTech Cselekvési Terv követett. A célok elérésének biztosítására az Európai Bankhatóság közzétette FinTech-munkatervét „Designing a Regulatory and Supervisory Roadmap for FinTech” (A FinTech Szabályozói és Felügyeleti Munkaterve) címen. Az EBH munkaterve fontos összefoglalása a hagyományos bankok és FinTech startupok által nyújtott szolgáltatásokhoz szükséges és tervezett szabályozói megközelítésnek. 
A FinTech unióban használatos definíciója tág, a szabályozó hatóságok azonban komoly erőfeszítéseket tesznek, a kockázatok csökkentése és a tisztességes versenyfeltételek biztosítása érdekében. Pragmatikus hozzáállást követnek, amely egy többszintű szabályozói struktúra köré szerveződik, a vállalatok, ügyfeleik, a pénzügyi szektor és a gazdaság egészének kockázatai szerint differenciált szabályozói követelményekkel. Elvben az a cél, hogy megfeleljenek az „azonos kockázat, azonos szabályok" elvárásnak.

Minden bizonnyal a pontos definíció hiánya váltotta ki az Európai Központi Bank (EKB) jelenlegi álláspontját, amely szerint a FinTech-szolgáltatások szabályozásának és felügyeletének egyelőre nemzeti hatáskörben kell maradnia. Önmagában ez a kijelentés is jól mutatja, hogy mennyire nehéz lenne jelenleg központilag szabályozni ezt a folyamatot és tevékenységet. A következő kihívás, hogy hogyan biztosíthatók az egyenlő versenyfeltételek a hagyományos bankok és a FinTech-szolgáltatók számára. Nem könnyű kiegyensúlyozott megoldást találni. Egy másik kényes probléma az adózás kérdése. Az uniós Digitális Egységes Piac kialakítása során az Európai Bizottság javaslatot tett egy Tanácsi irányelv elfogadására, amely lefektetné a jelentős digitális jelenlét társasági adózási szabályait.

A tanulmány következő fejezetében áttekintettük a FinTech megközelítését Kínában, ahol a FinTech-szektor gyorsan fejlődik és sok tekintetben globális vezető szerepet tölt be. Az ország digitális fizetései a globális volumen közel felét teszik ki, és az online személyközi (P2P) hitelezés a globális érték háromnegyedére rúg. Kína FinTech-szektora azonban most kulcsfontosságú válaszúthoz érkezett. Néhány évvel ezelőtt problémák jelentkeztek, amikor kockázatok merültek fel a P2P-platformok körül, és megugrott a feketegazdaság forrásbevonó és finanszírozó tevékenysége. Ez tanulságként és intő példaként szolgált a szabályozó és felügyeleti hatóságok számára, és megváltozott hozzáállásukra sok ország megszívlelendő és követendő példaként tekint. Egyébként a kínai megközelítés sok szempontból hasonlít az unióshoz. Például a Kínai Központi Bank (People’s Bank of China) véleménye szerint a FinTech-tevékenységeket illetően nincs egységes álláspont; a FinTech-ökoszisztéma javítása csökkenthet bizonyos jelentős kockázatokat; a szabályozás hatékonyságának erősítése érdekében a rendszer tökéletesítésére új ötleteket és megközelítéseket kell beépíteni. Ebben a helyzetben elengedhetetlen az önszabályozás elemének megkövetelése is.

Az uniós és kínai FinTech-megközelítés után üdítő áttekinteni a magyarországi helyzetet. Elmondhatjuk, hogy Magyarország nincs lemaradva még akkor sem, ha a szabályozók és hagyományos bankok hasonló feladatokkal néznek szembe, mint az Unió és Kína. E tekintetben a magyar jegybank legfrissebb felméréseire támaszkodtunk. Ígéretes folyamat indult el az innovatív termékek és megoldások banki múködésbe történő integrálására. 
A magyarországi bankok biztosak abban, hogy továbbra is meghatározó szerepük lesz a pénzügyi közvetítő rendszerben. Ugyanakkor a FinTech-cégek döntő többsége rendszeres kapcsolatban áll bankokkal vagy felkeresett már bankot az elindulása óta. A MNB-felmérés eredménye alapján a szabályozó és a felügyeleti hatóságok aktív bevonása szükséges ahhoz, hogy a különböző piaci szereplők és új belépők közötti verseny erősödjön, vagy együttmúködés alakuljon ki.

A magyar banki közösség véleménye szerint a digitalizáció nagyon nagy kihívást és kényszert jelen a bankszektor megújulása számára. A mai 20-30 évesek többsége nem fog bankfiókba járni, inkább minden tranzakciót mobiltelefonjukon bonyolítanak le. Megváltoznak az ügyfélszokások, a fiók jelentősége csökken, a technológia jelentősége pedig megnő. Általános és valós veszély, hogy számos bank szerepét át fogják venni új szereplők, például fizetési szolgáltatók.

Tanulmányunk címét Aldous Huxley (1894-1963) híres könyve, az 1931-ben megjelent „Szép új világ” ihlette. Huxley ironikusan bírálta a gépek világa által befolyásolt és irányított fogyasztói társadalmat, és közben megpróbálta megjósolni az emberiség jövőjét. A sci-fivel és tudományos elemekkel ötvözött jövőképének jelentős része megvalósult a következő évtizedekben. Úgy is mondhatnánk, hogy egy jobb szép új világ épült fel a gépek világából.

Nem vagyunk jövendőmondók, nem próbáljuk megjósolni a digitális pénzügyi átalakulás végső kimenetelét, de hisszük, hogy ez a fejlődés kedvező változásokat hozhat az emberiség számára. Mindazonáltal a banki tevékenységek és a pénzügyi szolgáltatások a gazdaság és a társadalom egészének legfontosabb elemei közé tartoznak, ezért mélyrehatóan elemeznünk kell a FinTech-fejleményeket. Látnunk kell, hogy vannak-e kockázatok, és amennyiben vannak, hogyan kezelhetők vagy mérsékelhetők.

Még a harmadik ipari forradalom kezdete után közel száz évvel is hiába próbálták a filozófusok összefoglalni a gépek és az emberek közötti kapcsolat természetét, és kifejteni nézeteiket a gépkorszaknak az emberi gondolkodásra és viselkedésre kifejtett hatásáról. Megítélésünk szerint ezek a kérdések a digitális átmenet korában jogosak, vagy legalábbis azok lehetnek, és a hagyományos bankok és ügyfeleik átalakulásának vizsgálatakor is jó okkal merülnek fel. A FinTech-nek végső soron jobb életet kell biztosítania az emberek számára.

Most pedig összefoglaljuk elemzésünk fő következtetéseit. Megállapíthatjuk, hogy a FinTech egy gyorsan változó és növekvő globális „forradalmi” fejlődési folyamat kezdeti szakasza. Ezért a korszaknak ez a része romboló változásokat is hozhat, a nyugodt, kiszámítható fejlődés ideje még nem érkezett el. Jóllehet a FinTech-beruházások rendkívül gyorsan bővülnek a pénzügyi piacokon, még távolról sem egyér- 
telmű, hogy milyen hatással lesz a bankokra és pénzügyi intézményekre. Az egész FinTech-et és annak szabályozását övező viták mögött a stabilitás és a verseny közötti feszültség húzódik meg, az Európai Unióban, Kínában és Magyarországon egyaránt.

A fejlődési folyamat e pontján annyit állapíthatunk meg, hogy a pénzügyi technológia gyors ütemben fejlődik, és a folyamat definíciója tág és folyamatosan változik. A gyors változások miatt a szabályozó és felügyeleti hatóságok nem a folyamatok előtt járnak, hanem igyekeznek felzárkózni az eseményekhez. A tág és meglehetősen megengedő definíció megnehezíti az egyenlő versenyfeltételek biztosítását a bankok és a FinTech startupok számára, ami a gyakorlatban annyit jelent, hogy a banki szabályozás és felügyelés szigorúbb.

A hagyományos bankok és a FinTech startupok közötti kapcsolat folyamatosan fejlődik és változik. Számos módon jellemezhetjük a két csoport közötti lehetséges kapcsolatot, például végzetes vonzalomként vagy veszedelmes viszonyként. Az elfogadás is változó: a folyamat hívei lelkesen üdvözlik a fejleményeket, a szkeptikusok azonban bizalmatlanok.

Bármi lesz is a FinTech-fejlődés kifutása, a fenti elemzésből látható, hogy rendkívül gyors és elkerülhetetlen folyamatnak vagyunk tanúi, amely hatással van a globális versenyképességre. Ebben a tanulmányban a FinTech-jelenség pontosabb megértését szándékoztunk elősegíteni, ezért is vizsgáltuk a hagyományos bankok és a FinTech startupok közötti lehetséges kapcsolatok alakulását. Megítélésünk szerint a bankok és a FinTech-cégek között több a közös üzleti érdek, mint ami megosztaná őket.

Ennek a digitális fejlődésnek a hátterében is emberek állnak, ezért az egyik nagy kérdés az, hogyan alakul át a társadalom a digitális forradalom alatt és után. A viszszatekintés néha segít megérteni a jövőbeli és jelenkori változásokat. Meglátásunkat egy Karl Jasperstől származó idézettel támasztjuk alá: „A technikától elözönlött világ mindennapi bonyolultsága arra kényszerít bennünket, hogy uralkodjunk a világ fölött abban a környezetben (Umwelt), amely megközelíthető a számunkra. A dolgokhoz való viszony megváltozott; a dolgok eltávolodnak tőlünk, közömbösekké válnak, miközben megváltoztathatatlan tényezők formáját veszik fel; a technika elszakította az embert a közvetlen jelentől. Az új feladat, amit végre kell hajtani, az, hogy a technikai alkotások segélyével újratalálja létének közvetlen jelenlétét a világot alkotó minden dolog számára. A technikai lehetőségek fejlődése folytán teremtett új feltételeket az ember szolgálatába kellene állítani (Jaspers 1946).

Számos közgazdász állítja, hogy az új világban a digitális a normális. Meglátásunk szerint érdemes a kijelentés végére kérdőjelet tenni. A jelenlegi gyors változások időszakában nem tudjuk, hogyan fest majd végül az „új világ”. „A hírekben a pénz- 
ügyi technológiákat »felforgatóként«, »forradalmiként « jellemzik, amelyek »digitális fegyverekkel« »lebontják« a korlátokat és a hagyományos pénzügyi intézményeket" (WEF 2017).

Jogos az a kérdés, hogy a társadalom és a gazdaság készen áll-e arra, hogy szembenézzen ezekkel a kihívásokkal. A válasz az, hogy nem. Minden szereplőnek megvan a maga felelőssége, beleértve a központi bankokat, a szabályozókat, a felügyeleti hatóságokat, a hagyományos bankokat, a fogyasztókat és a FinTech-vállalatokat is. Valamennyi szabályozó és felügyeleti hatóság csak követi a viharos sebességú eseményeket, pragmatikus definíciót alkalmaz, és igyekszik a főbb szereplők számára egyenlő feltételeket biztosítani; a hagyományos bankok és a FinTech-vállalatok egymást és a piacot is tesztelik, miközben egyre több FinTech-alkalmazást dolgoznak ki. A fogyasztók örülnek a gyorsabb és olcsóbb pénzügyi szolgáltatásoknak, de szükségük van a hagyományos bankok által nyújtott biztonságra, és elsősorban a már régóta piacon lévő bankokban bíznak.

A központi bankok és szabályozók többsége felhívja a figyelmet a potenciális kockázatokra. A kockázatértékelés nehézségekbe ütközik a gyorsan változó világban. Néha „gépek” gyűjtik össze és értékelik a kockázatértékeléshez szükséges adatokat. Korábban említettük, hogy az információ hatalom. A szabályozóknak szigorúan ragaszkodniuk kell ahhoz, hogy a FinTech-ek és pénzügyi szolgáltatók által összegyűjtött digitális adatokkal ne éljenek vissza az ügyfelek kárára.

A FinTech szolgáltatások gyors fejlődését a jelenlegi kegyelmi időszak is támogatta. A globális pénzügyi szektor immár közel egy évtizede háborítatlanul növekedhet. A lehetséges kockázatok igazi fokmérője egy újabb recesszió vagy válságperiódus lesz. A pénzügyi szektornak fel kell készülnie erre.

\section{Felhasznált irodalom}

Arner, D. W. - Barberis, J. - Buckley, R. P. (2015): The Evolution of FinTech: A New Post-Crisis Paradigm? University of Hong Kong Faculty of Law Research Paper No. 047, October.

Authority of the House of Lords (2018): Al in the UK: ready, willing and able? HL Paper 100. https://publications. parliament.uk/pa/ld201719/ldselect/ldai/100/100.pdf. Letöltés ideje: 2018. május 24.

BCBS (2018): Bázeli Bankfelügyeleti Bizottság: Sound Practices. Implications of FinTech developments for banks and bank supervisors. https://www.bis.org/bcbs/publ/d431.pdf. Letöltés ideje: 2018. május 24.

Buenstorf, G. (2016): Schumpeterian incumbents and industry evolution. Journal of Evolutionary Economics, 26(4): 823-836. https://doi.org/10.1007/s00191-015-0423-7 
Brock, D. C. (ed.) (2006): Understanding Moore's Law: Four Decades of Innovation. Philadelphia: Chemical Heritage Press.

Deloitte (2016): FinTech in the CEE region. https://www2.deloitte.com/ce/en/pages/aboutdeloitte/articles/fintech-cee-region.html. Letöltés ideje: 2018. május 24.

EBH (2018): Európai Bankhatóság: The EBA's FinTech Roadmap. Conclusions from the consultation on the EBA's approach to financial technology (FinTech). http://www.eba. europa.eu/documents/10180/1919160/EBA+FinTech+Roadmap.pdf. Letöltés ideje: 2018. május 24.

EKB (2017): Guide to assessments of fintech credit institution licence applications. Banking Supervision, European Central Bank. https://www.bankingsupervision.europa.eu/ legalframework/publiccons/pdf/licensing_and_fintech/ssm.guide_on_assessment_for_ licensing_of_fintech_credit_insts_draft.en.pdf. Letöltés ideje: 2018. május 24.

Enria, A. (2018): Designing a Regulatory and Supervisory Roadmap for FinTech.

Európai Bizottság (2017): The Digital Single Market State of Play. A tallini Digital Summitra készítve, 2017. szeptember 29. https://www.eu2017.ee/sites/default/files/2017-09/ EC\%20for\%20TDS_The\%20Digital\%20Single\%20Market\%20Strategy.pdf. Letöltés ideje: 2018. május 24.

Európai Bizottság (2018): Pénzügyi technológia: Új bizottsági intézkedések a versenyképesebb és innovativabb pénzügyi piac megvalósítása érdekében. Sajtóközlemény. Brüsszel, 2018. március 8. http://europa.eu/rapid/press-release_IP-18-1403_hu.htm

Fáykiss Péter - Papp Dániel - Sajtos Péter - Tőrös Ágnes (2018): A FinTech-innovációk ösztönzésének szabályozói eszközei: Innovation Hub és Regulatory Sandbox a nemzetközi gyakorlatban. Hitelintézeti Szemle, 17(2): 43-67. http://doi.org/10.25201/HSZ.17.2.4367

Hatami, A. (2015): The future of banking: four scenarios. http://banknxt.com/53478/futurebanking-scenarios/. Letöltés ideje: 2018. május 24.

Hu, B. - Yin, Z. - Zheng, L. (2016): Development of China's Financial Supervision and Regulation. Palgrave McMillan.

Jaspers, K. (1946): La Nef. Occidental Press. Washington D.C., 1967.

Kerényi Ádám - Müller János (2018): Experts' Comments from the Host Country. AFCA BOOKLET.

Kerényi Ádám - Molnár Júlia (2017): A FinTech-jelenség hatása - Radikális változás zajlik a pénzügyi szektorban? Hitelintézeti Szemle, 16(3): 32-50. http://doi.org/10.25201/ HSZ.16.3.3250 
Kerényi Ádám - Molnár Júlia - Müller János (2018): Veszedelmes viszonyok a bankok és a fintechek között? Gazdaság és Pénzügy, 2018(1): 86-97. http://www.bankszovetseg.hu/ Public/gep/2018/088-99ig\%20kerenyi-molnar-muller.pdf. Letöltés ideje: 2018. május 24.

Kim, Y. - Choi, J. - Park, Y.-J. - Yeon, J. (2016): The Adoption of Mobile Payment Services for "FinTech". International Journal of Applied Engineering Research, 11(2): 1058-1061.

KPMG (2018): The Pulse of Fintech H1 2018: The Pulse of Fintech 2018 Biannual global analysis of investment in fintech. https://assets.kpmg.com/content/dam/kpmg/xx/ pdf/2018/07/h1-2018-pulse-of-fintech.pdf. Letöltés ideje: 2018. december 24.

Kurzweil, R. (2006): The Singularity Is Near: When Humans Transcend Biology. New York: Penguin Books.

Li, X. (2017): China's Digital Economy and Made in China 2025. Institute of Industrial Economics, CASS.

McAuley, D. (2015): What is FinTech. Wharton FinTech. https://medium.com/whartonFinTech/what-is-FinTech-77d3d5a3e677. Letöltés ideje: 2018. szeptember 10.

McKinsey (2017): China's digital economy a leading global force. Vitaanyag.

McKinsey (2018): The Phoenix Rises: Remaking the Bank for An Ecosystem World. McKinsey Global Banking. Annual Review 2017.

Mészáros Tünde (2018): Beszámoló a Budapest Renminbi Kezdeményezés 2018. évi konferenciájáról. Hitelintézeti Szemle, 17(2): 156-160. http://www.hitelintezetiszemle.hu/ letoltes/hsz-17-2-kb1-meszaros.pdf

MNB (2017): Innováció és Stabilitás - FinTech körkép Magyarországon. Konzultációs dokumentum.

Patai Mihály (2018): Interjú. Aréna. Inforádió. https://infostart.hu/video/oTiVHDCltzw. Letöltés ideje: 2018. május 24.

PWC China (2017): Global FinTech Survey China Summary 2017. https://www.pwccn.com/ en/industries/financial-services/publications/global-fintech-survey-china-summary-2017. html. Letöltés ideje: 2018. május 24.

Taylor, C. (2017): The Golden Age of FinTech is Here, According to Fintech Evangelist Ron Suber. http://finteknews.com/golden-age-FinTech-according-FinTech-evangelist-ron-suber/.

Thurzó Ádám (2017): Példátlan húzásra készül az MNB, egy csapásra egy új világba repítik Magyarországot. Portfolio.hu https://www.portfolio.hu/vallalatok/it/peldatlan-huzasrakeszul-az-mnb-egy-csapasra-egy-uj-vilagba-repitik-magyarorszagot.265025.html. Letöltés ideje: 2018. december 24. 
Varga Bence (2017): A kínai pénzügyi felügyelést érintő aktuális kihívások és kezelésük. Hitelintézeti Szemle, 16(Különszám): 126-139. http://www.hitelintezetiszemle.hu/letoltes/ varga-bence.pdf

WEF (2017): Világgazdasági Fórum: Beyond FinTech: A Pragmatic Assessment of Disruptive Potential In Financial Services. http://www3.weforum.org/docs/Beyond_FinTech___A_ Pragmatic_Assessment_of_Disruptive_Potential_in_Financial_Services.pdf. Letöltés ideje: 2018. május 24. 